This is an Accepted Manuscript of an article to be published by Cambridge University Press

in International \& Comparative Law Quarterly, available online on Cambridge Core:

https://www.cambridge.org/core/journals/international-and-comparative-law-

quarterly/article/div-classtitleshould-international-law-recognize-a-right-of-humanitarian-

interventiondiv/BB33A4BD19815812A9E48FF5F271357E

This version is not for citation. Please cite to published version.

\title{
SHOULD INTERNATIONAL LAW RECOGNIZE A RIGHT OF HUMANITARIAN INTERVENTION?
}

\author{
CHRIS O'MEARA ${ }^{*}$
}

\begin{abstract}
The on-going Syrian civil war calls for a re-evaluation of using force to protect human rights. This article does not rake over the much-debated issue of whether a right of humanitarian intervention exists as lex lata. Instead, it addresses the little reviewed normative issue of whether the right should exist in international law to support and reflect a pluralistic understanding of sovereignty. Despite advancements in international human rights law, international humanitarian law and international criminal law, this wider fabric of international law preserves Westphalian sovereignty and the principle of non-intervention. It denies any right of humanitarian intervention.
\end{abstract}

Keywords: humanitarian intervention; sovereignty; international human rights law; international humanitarian law; international criminal law; jus ad bellum.

\section{INTRODUCTION}

The on-going humanitarian tragedies of the Syrian civil war call for a re-evaluation of using force to protect human rights. Now, over five years into the conflict, this call remains as loud and relevant as ever. That military action might be used to save lives is an idea long espoused in international law. In modern times, the debate regarding the existence of such right is framed within the boundaries of the Charter of the United Nations (UN Charter) and the collective security system. In this context, a right of humanitarian intervention refers to an independent legal basis, absent State consent, United Nations Security Council (UNSC) authorization or justifications of self-defence, for a State to use unilateral military force to protect individuals from egregious breaches of human rights occurring in a third State. ${ }^{1}$

* PhD Candidate and Teaching Fellow, Faculty of Laws, University College London. Email: christopher.o'meara@ucl.ac.uk. The author is grateful for the comments of Dr Kimberley Trapp. Any errors remain his own.

${ }^{1}$ Art 2(4) UN Charter prohibits the 'threat or use of force against the territorial integrity or political independence of any state'. In addition to State consent, the only explicit exceptions to this prohibition in the UN Charter are the inherent right of self-defence under Art 51 UN Charter and force authorized by the UNSC pursuant to Chapter VII UN Charter. 
Much of the debate has focused on the lex lata. That is to say the question of whether current international law recognizes the right of humanitarian intervention, based on State practice, that might give rise to a customary norm and/or a reinterpretation of the UN Charter. Whilst by no means settled, the better view is that there is no clear right of humanitarian intervention in international law. ${ }^{2}$ This article does not seek to add to this particular existential debate. Instead, regardless of the lex lata position, its focus is on the normative question of whether, as part of the wider fabric of international law, there should be a right of humanitarian intervention. In so doing, it addresses the invitation by Daniel Bethlehem in 2013 to knit together various threads of international legal practice to establish a 'tapestry argument' for such right. ${ }^{3}$

Tackling this issue requires an examination of the tensions that humanitarian intervention raises between State sovereignty on the one hand and the preservation of human rights on the other. Central to this analysis is how international law increasingly recognizes the need to safeguard human beings. As part of this trend, this article explores certain of Bethlehem's core 'threads', these being developments since World War II in international human rights law (IHRL), international humanitarian law (IHL) and international criminal law (ICL). Together, these advancements point to a paradigm shift in the foundations of international law that emphasizes the security of persons and peoples instead of only States.

The key question to be examined is whether this evolution in the fabric of international law has affected the nature and extent of State sovereignty to such a degree that a right of humanitarian intervention should exist to reflect and support it. We will see that there has indeed been movement away from State centrism to a more pluralistic understanding of sovereignty. This 'pluralistic view' of sovereignty is one that increasingly recognizes the importance of human beings and their security, in addition to the traditional focus on States. It also requires sovereignty to be viewed as conditional on respecting and securing humanitarian protections. However, whilst a right of humanitarian intervention might initially appear attractive to protect and promote these developments, such a conclusion goes too far. Significantly, secondary rules of international law that relate to the enforcement of primary norms and respond to their violation are not supportive of the right. Instead, these secondary rules retain States as the principal actors in international law, preserving their external sovereignty and the attendant principle of non-intervention. By doing so, international law prioritizes other concerns, such as the comity of States and international peace and security,

\footnotetext{
${ }^{2}$ For a recent summary of the issues and relevant State practice, see S Rodley, 'Humanitarian Intervention' in $\mathrm{M}$ Weller (ed), Oxford Handbook on the Use of Force in International Law (Oxford University Press 2015) 775. In terms of the latest State practice, Syria represents an opportunity lost for those, like Koh, who support such a right and was looking to Syrian intervention as a law making moment to crystallise a new norm of customary international law. H Koh, 'Syria and the Law of Humanitarian Intervention (Part II: International Law and the Way Forward)' (EJIL: Talk!, 4 October 2013) <http://www.ejiltalk.org/syria-and-the-law-of-humanitarianintervention-part-ii-international-law-and-the-way-forward/>. Instead, Syria points to the contrary, suggesting a halt to any supposed momentum behind customary development. When military action finally occurred, it was not based on humanitarian intervention. The governments of the United States, Canada, Turkey, UK, Australia and France instead justified their military response against Daesh/ ISIS in Syria on the basis of individual selfdefence and/or the collective self-defence of Iraq. See UN Doc S/2014/695 (23 September 2014) (United States), UN Doc S/2015/221 (31 March 2015) (Canada), UN Doc S/2015/563 (24 July 2015) (Turkey), UN Doc S/2015/688 (7 September 2015) (UK), UN Doc S/2015/693 (9 September 2015) (Australia), UN Doc S/2015/745 (9 September 2015) (France). Russia's intervention was based President Assad's consent. 'Russia joins war in Syria: Five key points', BBC News (1 October 2015) <http://www.bbc.co.uk/news/world-middle-east34416519>. See further A Henriksen and M Schack, 'The Crisis in Syria and Humanitarian Intervention' (2014) 1 Journal on the Use of Force and International Law 122.

${ }^{3}$ D Bethlehem, 'Stepping Back a Moment - The Legal Basis in Favour of a Principle of Humanitarian Intervention' (EJIL: Talk!, 12 September 2013) <http://www.ejiltalk.org/stepping-back-a-moment-the-legalbasis-in-favour-of-a-principle-of-humanitarian-intervention/ $>$.
} 
even if this is to the detriment of human rights. On a close review, the threads of Bethlehem's tapestry argument are in fact inimical to a right of humanitarian intervention. In addition, we must recognize the difficulties that surround the practical application of coercive military force for humanitarian purposes and the inherent dangers of its abuse. These raise significant concerns regarding the possible effect of humanitarian intervention on international law more generally. This putative right simply does not fit within this broader framework. The result is that the broad prohibition on the use of force holds true and this should remain. International law should not recognize a right of humanitarian intervention.

\section{THE NORMATIVE CLAIM}

Bethlehem has pointed to certain trends in international law that might establish a right of humanitarian intervention. His argument is based on a 'tapestry' of threads of practice, which includes the responsibility to protect doctrine (R2P) State practice, the human rights objectives of the UN and shifts in international law that he perceives to be supportive of the right. ${ }^{4}$ These shifts also include developments in IHRL, IHL and ICL. Along the same lines, Teitel speaks of 'humanity law', arguing that there has been a paradigm shift in international law from emphasizing State security to the security of persons and peoples. ${ }^{5}$ The focus of this section, and the article more generally, is the role that this claim of a 'paradigm shift' plays in respect of a right to use force outside of the explicit parameters of the UN Charter. Assessing this claim requires an analysis of the changing nature of State sovereignty and the progression from a purely State-centric conception of international law to one where individuals are increasingly the focus. The question therefore is how far does a modern understanding of sovereignty take us, in terms of whether international law should recognize a right of humanitarian intervention to reflect and support these developments?

\section{A. Sovereignty and State centrism}

The classical positivist conception of international law and State sovereignty poses significant challenges to a putative right of humanitarian intervention. Such a right is juxtaposed against a commitment to State sovereignty that is often associated with the Peace of Westphalia 1648 and the attendant principles of territorial integrity and non-intervention. ${ }^{6}$ In the Vattelian tradition, ${ }^{7}$ positivism premised that States were the exclusive and equal subjects of an international law that only regulated the rights and duties of States in relation to each other. ${ }^{8}$ The meaning and extent of the notion of 'sovereignty' is a dynamic and much debated subject. ${ }^{9}$

\footnotetext{
${ }^{4}$ Bethlehem (n 3). He is backed by commentators such as Koh (n 2).

${ }^{5}$ R G Teitel, Humanity's Law (Oxford University Press 2011).

${ }^{6}$ Positivism as a jurisprudential ideology really took hold in the $19^{\text {th }}$ century. This 'positive revolution' put the will and consent of States (rather than divine or natural law) at the centre of international rule making. See e.g. S C Neff in M D Evans (ed), International Law (4th edn, Oxford University Press 2014) 13-17 for a further discussion of this development. For an overview of the Peace of Westphalia and its impact on the evolution of international law and the rise of the sovereign State, see e.g. L Gross, 'The Peace of Westphalia, 1648-1948' (1948) 42(1) AJIL 240.

${ }^{7}$ E Vattel, The Law of Nations, Or, Principles of the Law of Nature, Applied to the Conduct and Affairs of Nations and Sovereigns (1797, reprinted, Indianapolis: Liberty Fund, 2008).

${ }^{8}$ L Oppenheim, International Law: A Treatise, Vol. I (Hersch Lauterpacht (ed), $7^{\text {th }}$ edn, Longmans, Green \& Co. 1952) 341.

${ }^{9}$ L Henkin, 'That S Word: Sovereignty, and Globalization, and Human Rights, Et Cetera' (1999) 68 Fordham Law Review 1; N Schrijver, 'The Changing Nature of State Sovereignty' (2000) 70(1) B.Y.I.L. 65, 69-72; M
} 
For present purposes however, external sovereignty ${ }^{10}$ is usually understood as the ability of States to act on the international plane on an equal basis with other States and without interference in their internal affairs by any higher legal authority or other State (other than by consent). ${ }^{11}$ This classic model of sovereignty thereby evokes an image of a protective shell that surrounds and shields the internal affairs of the State from the outside world. Whilst by no means an absolute layer of protection, it suggests a degree of opacity or impermeability that insulates the State from external scrutiny and interference. It leaves them largely unconstrained in terms of what they may do within their own borders, subject only to international law to which they have consented or which is jus cogens.

This idea of external sovereignty was first espoused in a time when there was a limited conception of individual rights. Consequentially, the rights of States were placed above those of individuals, who were viewed as objects, rather than subjects, of international law. ${ }^{12}$ In addition, external sovereignty guaranteed the inviolability of a State's borders, denying any right of intervention, let alone humanitarian intervention, in the event that a State mistreated those on its territory. We have moved away from this strict positivist view however, to a modern understanding of external sovereignty that counters, to some extent, both of these consequences. First, whilst States may be the primary actors, the International Court of Justice (ICJ) recognized relatively quickly after the creation of the UN that there may be other subjects of international law that are not States. ${ }^{13}$ Such view has since developed, with much being written about the increased significance of non-State actors (NSAs) within the international legal order and how the balance between individual and State interests has been readjusted in favour of the former. Indeed, some commentators have gone so far as to argue that the primary subject of international law is now the individual and not the State. Lauterpacht and McCorquodale for example have posited that human rights are superior to those of the sovereign State. ${ }^{14}$ This developed understanding of sovereignty will be discussed below in respect of advancements in the primary rules of IHRL, IHL and ICL.

Secondly, it is true that the principle of non-intervention remains a cornerstone of modern international law. The Friendly Relations Declaration reminds us that '[n]o state or group of states has the right to intervene, directly or indirectly, for any reason whatever, in the internal or external affairs of any other state. ${ }^{15}$ However, this principle must be viewed in the light of

Koskenniemi, Apology to Utopia: The Structure of International Legal Argument (Cambridge University Press 2006) 228-45.

${ }^{10}$ Koskenniemi, ibid 240-5; D Held, 'Law of States, Law of Peoples: Three Models of Sovereignty' (2002) 8 Legal Theory 1, 3-4. In contrast, internal sovereignty speaks to the make-up of a State and its exclusive authority over its territory and people. Crawford calls this 'a monopoly of governing authority', J Crawford and M Koskenniemi, The Cambridge Companion to International Law (Cambridge University Press 2013) 120.

${ }^{11}$ Schrijver (n 9); Held, ibid 3; J Crawford (ed), Brownlie's Principles of Public International Law ( $8^{\text {th }}$ edn, Oxford University Press 2008) 447-8.

${ }^{12}$ See further, R Higgins, Problems and Process: International Law and How We Use It (Oxford University Press 1994) 48-55.

${ }^{13}$ Reparation for Injuries Suffered in Service of the United Nations (Advisory Opinion) [1949] ICJ Rep 174, 178179.

${ }^{14}$ H Lauterpacht, International Law and Human Rights (Stevens \& Sons 1950) 67-72; R McCorquodale in Evans (n 6) 301. For further discussion of the importance of NSAs in the sovereignty calculus and the rebalancing in favour of human beings, see M Reisman 'Sovereignty and Human Rights in Contemporary International Law' (1990) 84 AJIL 866; L Henkin 'Human Rights and State "Sovereignty"' (1995-6) 25 Georgia Journal of International and Comparative Law 31; A Peters 'Humanity as the A and $\Omega$ of Sovereignty' (2003) 20 EJIL 513; Schrijver (n 9) 88-9; Teitel (n 5); K N Trapp, 'Actor-pluralism, the 'turn to responsibility' and the jus ad bellum: 'unwilling or unable' in context' (2015) 2 Journal on the Use of Force and International Law 199.

${ }^{15}$ UNGA Res 2625 (XXV), Declaration on Principles of International Law Concerning Friendly Relations and Co-operation Among States in Accordance with the Charter of the United Nations (1970) (Friendly Relations Declaration). This is subject to the right of self-defence under Art 51 UN Charter and to UNSC authorized enforcement action under Charter VII UN Charter. 
a modern understanding of sovereignty, which no longer constitutes an absolute shield of protection from the observation, criticism and reaction of third States and international organisations. It is conditional, carrying with it certain obligations and responsibilities towards individuals. The contemporary position is that each State must 'respect the dignity and basic rights of all the people within the state ${ }^{16}$ and has 'the responsibility to protect its populations from genocide, war crimes, ethnic cleansing and crimes against humanity'. ${ }^{17}$ Under this muchcelebrated R2P formulation, where a State fails in its responsibility to protect, the international community has reserved the right, as a last resort, to take collective forcible action through the $\mathrm{UN}$ to enforce it.

In respect of how far this re-characterization of sovereignty goes and whether it is supportive of a right of humanitarian intervention, it must first be noted that $\mathrm{R} 2 \mathrm{P}$ is a political doctrine and not a formal or even material source of international law. ${ }^{18}$ Moreover, the use of force is a last resort under this principle and, relying as it does on Chapter VII UN Charter authorization, by definition it is not (unilateral) humanitarian intervention. Crucially, the World Summit Outcome Document did not endorse ICISS's proposal that where the UNSC did not act militarily for human protection purposes, then the UN General Assembly (UNGA) (under the Uniting for Peace Resolution ${ }^{19}$ ) and/or regional organisations might do so. ${ }^{20}$ Therefore, whilst R2P contemplates that force may be used to intervene in domestic affairs to protect human rights, it clearly and explicitly protects the primacy of the UNSC in authorizing that use of force. It is also supportive of the sovereign prerogatives of States, recognizing that the primary responsibility to protect their citizens lies with them. The doctrine does however indicate some willingness (even if it is not always forthcoming) on behalf of the international community to monitor and enforce respect for human rights where a State fails to adhere to a duty to protect its own citizens. It is also indicative, as Reisman notes, of the effect of the human rights movement on sovereignty that has meant that the fulcrum of international law has shifted from the protection of sovereigns to the protection of people. ${ }^{21}$ Respect for human rights is becoming more mandatory and respect for sovereignty less absolute. ${ }^{22}$ States are therefore not the sole centres of legal power. Rather, their relations and activities are shaped and formed by an overarching cosmopolitan legal framework. ${ }^{23}$ These conclusions will be explored further in the following sections.

\section{B. International human rights law}

It is in the field of IHRL where we see the biggest shift towards individuals and their security. This movement has had important consequences for internal sovereignty and the relationship between individuals and the State. More importantly for any potential right of humanitarian intervention however, is the effect on external sovereignty and the limitations placed on State power. Because of the growing importance of IHRL, States may no longer mistreat those within their jurisdiction and remain immune from the reaction of the wider international community. Mechanisms now exist to monitor State action and, in certain instances, to call States to account

\footnotetext{
${ }^{16}$ Report of the International Commission on Intervention and State Sovereignty (ICISS), The Responsibility to Protect (2001) para 1.35.

${ }^{17}$ World Summit Outcome Document 2005, paras 138-9, adopted by UNGA Res A/RES/60/1 (2005).

${ }^{18}$ Art 38(1) Statute of the International Court of Justice, 26 June 1945, 15 UNCIO 355. For a fuller analysis of the R2P doctrine and its status in international law, see e.g. Henriksen and Schack (n 2) 128-33.

${ }^{19}$ UNGA Res 377 (V) (1950).

${ }^{20}$ ICISS Report (n 16) paras $6.28-6.40$.

${ }^{21}$ Resiman (n 14) 872.

${ }^{22}$ Statement of The Netherlands Delegate, UN Doc S/PV.4011, 12.

${ }^{23}$ Held (n 10) 32-33.
} 
for any breaches of IHRL. The hurdle for a right of humanitarian intervention is that this inroad into State power only goes so far and enforcement of IHRL retains the central elements of State consent and focuses on peaceful dispute resolution.

\section{IHRL and the turn to human security}

Following the horrors of World War II, Article 1(3) UN Charter placed human rights and therefore individuals at the centre of the UN Charter system. Since then, a series of international human rights treaties have developed the movement to a humanity-based law. ${ }^{24}$ Most important are the International Covenant on Civil and Political Rights (ICCPR) and the International Covenant on Economic, Social and Cultural Rights, being binding multilateral treaties that sprang from the Universal Declaration of Human Rights. ${ }^{25}$ Together these form the 'International Bill of Human Rights'. The creation of regional human rights systems, most notably the Inter-American and European regimes, has strengthened these important humanitarian foundations. This package of international and regional treaties has mainstreamed human rights in international law and established a series of obligations that States owe to individuals subject to their jurisdiction.

The effectiveness of these treaties and institutions, including their limitations and failures, may certainly be debated. Grievous human rights breaches still occur and much more still needs to be done in this field. Yet, IHRL developments have been significant. Whilst States may make reservations to human rights treaties, thereby excluding or modifying their human rights obligations under them, by signing up to them they recognize that this subject matter is no longer the sole prerogative of the State. Even States with highly questionable human rights records submit to the Universal Periodic Review procedure by the Human Rights Council2 ${ }^{26}$ and the most authoritarian of regimes would not now deny that their citizens have certain fundamental rights. ${ }^{27}$ At the very least, this evidences State engagement with human rights and recognizes the fact that international standards have replaced once-sovereign standards (or lack of standards). ${ }^{28}$ In addition, IHRL has raised expectations on States to adhere to these standards and has increasingly prioritized them in international relations. Indeed, the core of human rights law has been recognized by the ICJ as constituting obligations erga omnes that are therefore the concern of all States. ${ }^{29}$ Human rights are therefore viewed as universal and, as will be explored below, their growing importance has influenced the development of IHL and ICL. Such evolution is also evidenced in the UN's increased willingness to concern itself with internal conflicts where humanitarian emergencies are present and even to characterize them as a threat to the peace, breach of the peace or an act of aggression for the purpose of Article

\footnotetext{
${ }^{24}$ A list of the ten core international human rights instruments and their monitoring bodies is available at <http://www.ohchr.org/EN/ProfessionalInterest/Pages/CoreInstruments.aspx $>$.

${ }^{25}$ Respectively, International Covenant on Civil and Political Rights, 16 December 1966, 999 UNTS 171; International Covenant on Economic, Social and Cultural Rights, 16 December 1966, 993 UNTS 3; UNGA Res A/RES/3/217 A (1948), Universal Declaration of Human Rights.

${ }^{26}$ See e.g. Saudi Arabia's 2013 National Report to the Human Rights Council, UN Doc A/HRC/WG.6/17/SAU/1.

${ }^{27}$ See e.g. E Bates in D Moeckli et al, International Human Rights Law (Oxford University Press, 2010) 37.

${ }^{28}$ Henkin (n 9) 4.

${ }^{29}$ Barcelona Traction, Light and Power Company, Limited (Belgium v Spain); Second Phase [1970] ICJ Rep 3, paras 33 and 34. Section II(E)(3) considers the repercussions of this characterization.
} 
39 UN Charter and its exercise of Chapter VII powers. ${ }^{30}$ Humanitarian concern is also more readily deployed in the language that States use to justify their actions. ${ }^{31}$

\section{Impact on external sovereignty}

IHRL's contribution to Bethlehem's tapestry argument and to Teitel's conception of humanity law is therefore significant. In terms of internal sovereignty, the relationship between individuals and the State has shifted, with the balance of power and the rights of protection increasingly favouring the individual. Most relevant for an assessment of any right of humanitarian intervention however, is the effect that such movement has had on external sovereignty and the ability of third States and international bodies to peer through the previously impermeable shell of non-intervention and to monitor and attempt to enforce compliance with human rights norms. In this regard, States have established a network of treaty monitoring bodies and human rights courts to review the actions of States vis-à-vis individuals. ${ }^{32}$ Individuals in certain cases are now empowered to bring claims directly against States for breaches of human rights obligations. The ECHR is the best example of the control mechanisms that may be deployed. Together with the Inter-American system, the ECHR regime provides individuals with the strongest means to protect and enforce their rights at the international level. ${ }^{33}$ Pursuant to Article 34 ECHR, any individuals subject to a State's jurisdiction have direct access to the ECtHR to bring a claim against that State. The Court's jurisdiction is compulsory (Article 32 ECHR) and its decisions binding (Article 46 ECHR).

In respect of internal sovereignty, ECHR mechanisms constitute a powerful means by which individuals can challenge national laws, resulting not only in declaratory relief and compensation, but also remedial action. This may even include requiring legislative changes. In Greens for example, the UK was directed to amend legislation regarding prisoner votes. ${ }^{34}$ This caused a 'mini-constitutional crisis' in the UK, raising fears that judges were threatening the sovereign will of Parliament. ${ }^{35}$ That an international court may challenge State power in this way has important consequences for external sovereignty. It shows that deference to the State is not absolute. Furthermore, it allows the veil of external sovereignty to be pierced by an outside body deploying international laws to protect and enforce individual rights within the State. IHRL may therefore allow intervention into what was previously viewed as the domestic reserve.

Interesting for the analysis of any right of humanitarian intervention is how this interference with sovereign power may apply when States act beyond their own borders, especially when

\footnotetext{
${ }^{30}$ See Danish Institute of International Affairs, Humanitarian Intervention: Legal and Political Aspects (Gullanders, 2000) 64-72 for a discussion of this development. The latest example is UNSC Res 1973 where a R2P style re-characterization of sovereignty was ostensibly invoked to authorize the intervention in Libya (see $n$ 112 and accompanying text).

${ }^{31}$ Teitel (n 52) 111, describing the interventions in Afghanistan and Iraq. See also note 158 regarding Russia's intervention in Ukraine.

${ }^{32}$ E.g. the Human Rights Committee that monitors implementation of the ICCPR and the European Court of Human Rights (ECtHR), which is the standing court of the European Convention on Human Rights (ECHR).

${ }^{33}$ This is particularly evident when contrasted with the UN Charter and international treaty systems that do not provide the same level of enforceability via compulsory jurisdiction and binding decisions. Similarly, the protection and enforcement of human rights in Africa, including via the African Commission on Human and Peoples' Rights and the African Court on Human and Peoples' Rights, face significant challenges. See M Schmidt, 391-432, and C Heyns and M Killander, 479-497, in Moeckli et al (n 27) for an overview of these systems.

${ }^{34}$ Greens and M.T. v United Kingdom (2010) 53 EHRR 21.

${ }^{35} \mathrm{P}$ Leach, 'No longer offering fine mantras to a parched child? The European Court's developing approach to remedies' in A Føllesdal (ed), Constituting Europe: The European Court of Human Rights in a National, European and Global Context (Cambridge University Press 2013) 166.
} 
they take part in armed conflicts abroad. Whilst the extraterritorial application of IHRL is a controversial and contested subject, it is increasingly recognized that, in respect of both international conventions ${ }^{36}$ and regional treaties, ${ }^{37}$ where States exercise control over territory or persons, then human rights obligations might follow and restrain States in their actions abroad. In principle at least, IHRL continues to apply during armed conflicts ${ }^{38}$ and, whilst the exact boundaries of such concept are still being explored and debated, the judicial approach seems to be that 'those who export war ought to see to the parallel export of guarantees against the atrocities of war'. ${ }^{39}$ Therefore, international law not only concerns itself with how States interact with each other, but also how States treat each other's nationals when they are acting outside their own territory. Such nationals thereby receive the benefit of IHL protections (as discussed below) and also potentially IHRL, which might give them a right of remedial action against the breaching State (as was the case in Al-Skeini). This shows that IHRL increasingly has the potential to protect individuals wherever they are found in the world and regardless of which State may be mistreating them.

These developments in IHRL appear significant for the present analysis of external sovereignty. However, have they rendered permeable its protective shell to such an extent that they point to a right for a State to export human rights protections by using force? Conceptually, this could be justifiable as those States that breach certain core rights lose their immunity from external coercive interference. ${ }^{40}$ The problem with this argument however, is how IHRL has developed and how it is enforced. In respect of its development, this has largely been through the acts of States themselves. By becoming a party to human rights treaties ${ }^{41}$ States have voluntarily accepted (or not) monitoring by the treaty bodies they establish, the jurisdiction of regional human rights courts and any restrictions on their power. The right to enter into international engagements is an attribute of State sovereignty. ${ }^{42}$ Thus, the public order nature of IHRL largely derives from State consent. ${ }^{43}$ Even more decisive to the inquiry is that the mechanisms of enforcement of the primary norms of IHRL are entirely consensual and peaceable. Under international treaties, such as the ICCPR, the wrongdoing State is 'part of the dialogue' with treaty monitoring bodies. Recommendations are made to States and solutions reached (or not) by way of mutual agreement. States may reject recommendations and no binding decision may be forced upon them. Even the strongest and most intrusive vehicle for the enforcement of human rights (being the judicial exercise of compulsory jurisdiction under the ECHR) relies on and preserves that consent. States have agreed to be part of a process that

\footnotetext{
${ }^{36}$ In respect of the extra-territorial application of the ICCPR, see e.g. Lopez Burgos v Uruguay, Merits, Communication No 52/1979, UN Document CCPR/C/13/D/52/1979, IHRL 2796 (UNHRC 1981); Legal Consequences of the Construction of a Wall in the Occupied Palestinian Territories (Advisory Opinion) [2004] ICJ Rep 136; UN Human Rights Committee, General Comment No. 31, Nature of the General Legal Obligation on States Parties to the Covenant, CCPR/C/21/Rev.1/Add.13 (2004).

${ }^{37}$ In respect of the extra-territorial application of the Inter-American regime, see e.g. Coard et al v United States, Report N. 109/99 - Case 10.951, Inter-American Commission on Human Rights, 29 September 1999. In respect of the extra-territorial application of the ECHR, see e.g. Al-Skeini and others $v$ United Kingdom (App No. 55721/07) 7 July 2011; Smith and others $v$ The Ministry of Defence [2013] UKSC 41.

${ }^{38}$ Palestinian Wall (n 36) para 106.

${ }^{39}$ Al-Skeini (n 37), Opinion of Judge Bonello, para 38.

40 J Rawls, The Law of Peoples (Harvard University Press 1999).

${ }^{41}$ Although customary international law, jus cogens and general principles may also be sources of IHRL. However, for analysis of the difficulties for IHRL with these sources, see B Simma and P Alston 'The Sources of Human Rights Law: Custom, Jus Cogens, and General Principles' (1992) 12 Australian Yearbook of International Law 82.

${ }^{42}$ SS “Wimbledon" (1923) PCIJ Ser A, No 1, 25.

${ }^{43}$ Although elements of irrecusability may also arise in IHRL, where State consent is questionable. See H R Fabri in P Alston and E Macdonald (eds), Human Rights, Intervention, and The Use of Force (Oxford University Press 2008) 50-53.
} 
focuses entirely on peaceful dispute resolution. ${ }^{44}$ In both cases, the State is included in the pursuit of enforcing the primary norm by way of pacific settlement. This is inimical to any right of humanitarian intervention that entirely excludes the State from the process of resolution, displaces its external sovereignty and territorial integrity and uses force to do so.

\section{International Humanitarian Law}

Like IHRL, developments in IHL have also increasingly focused on human security, with consequential checks placed on State power. In this regard, IHL requires States to walk a fine line, allowing them freedoms to respond to the demands of military necessity and the pragmatics of war, whilst curbing their freedom of action in the name of humanitarianism. ${ }^{45}$ IHL has witnessed a remarkable shift since World War II, restricting not only how States use force against each other, but also how they use force within their own borders against NSAs. This inroad into State sovereignty is significant. Running parallel with the general trend in IHRL, such developments seem potentially supportive of a right of humanitarian intervention. However, external sovereignty remains a check on outside interference and even though IHL protects individuals, breaches of it are primarily dealt with ex post facto via ICL. As with IHRL therefore, enforcement relies on consent and peaceful dispute resolution, which does not favour a right of humanitarian intervention.

\section{IHL and the turn to human security}

In terms of focusing on individuals, IHL and IHRL possess similar core goals, which include a common nucleus of non-derogable rights and a shared purpose of promoting life and human dignity. ${ }^{46}$ IHL therefore limits the means and methods of warfare (including prohibiting certain weapons and tactics) $)^{47}$ as well as protecting civilians who are not taking part in hostilities and combatants placed hors de combat. ${ }^{48}$ Important for the present analysis is that two 'intransgressible' principles run through the provisions of both Hague Law and Geneva Law and are considered customary international law. ${ }^{49}$ The first is the principle of distinction between combatants and non-combatants. It is aimed at protecting civilians not taking part in hostilities by prohibiting the targeting of them. ${ }^{50}$ The second is the prohibition of causing unnecessary suffering to combatants. This may be referred to as a principle of humanity, as

\footnotetext{
${ }^{44}$ This will be discussed further in Section II(E).

${ }^{45}$ Y Dinstein, The Conduct of Hostilities under the Law of International Armed Conflict ( $2^{\text {nd }}$ edn, Cambridge University Press 2010) 5.

${ }^{46}$ Inter-American Commission on Human Rights, Precautionary Measures in Guantánamo Bay, 12 March 2002, International Legal Materials 41 (2002) 532.

${ }^{47}$ Principally through the law codified by The Hague Conventions and Declarations of 1899 and 1907, available at <http://www.icrc.org/applic/ihl/ihl.nsf/vwTreatiesByDate.xsp > (Hague Law).

${ }^{48}$ Principally via: Geneva Convention (I) for the Amelioration of the Condition of the Wounded and Sick in Armed Forces in the Field, 12 August 1949, 75 UNTS 31; Geneva Convention (II) for the Amelioration of the Condition of Wounded, Sick and Shipwrecked Members of Armed Forces at Sea, 12 August 1949, 75 UNTS 85; Geneva Convention (III) Relative to the Treatment of Prisoners of War, 12 August 1949, 75 UNTS 135; Geneva Convention (IV) relative to the Protection of Civilian Persons in Time of War, 12 August 1949, 75 UNTS 287; Protocol Additional to the Geneva Conventions, 12 August 1949, and Relating to the Protection of Victims of International Armed Conflicts, 8 June 1977, 1125 UNTS 3 (API); Protocol Additional to the Geneva Conventions, 12 August 1949, and Relating to the Protection of Victims of Non-International Armed Conflicts, 8 June 1977 , 1125 UNTS 609 (APII) (Geneva Law).

${ }^{49}$ Legality of the Threat or Use of Nuclear Weapons (Advisory Opinion) [1996] ICJ Rep 226, paras 78-79.

${ }^{50}$ This principle is codified in Art 48 API and is reinforced by the principle of proportionality that effectively prohibits military attacks where civilian losses would be disproportionate to the military advantage.
} 
also reflected in the Martens Clause. ${ }^{51}$ A great many rules of IHL therefore are fundamental to the respect of the human person and to 'elementary considerations of humanity'. ${ }^{52}$ Notable is Common Article 3 to the Geneva Conventions that prohibits murder, torture and cruel and degrading treatment. Whilst originally directed at non-international armed conflicts (NIACs), ${ }^{53}$ this is now regarded as custom applicable to all armed conflicts and constitutes the 'minimum yardstick' of fair and humane treatment. ${ }^{54}$ IHL therefore seeks to provide a comprehensive set of protections for all individuals, whether combatants or civilians, who are caught up in armed conflict. States are obligated to respect and protect these fundamental rules and principles. Whether these developments are supportive of a right of humanitarian intervention however, depends on their impact on external sovereignty.

\section{Impact on external sovereignty}

The work of the international criminal tribunals has been instrumental to how IHL has impacted on external sovereignty. Paramount was the Tadić case, in which the International Criminal Tribunal for the former Yugoslavia (ICTY) found that a body of customary international law (including elements of both Geneva Law and Hague Law) had arisen that applied to both international armed conflicts (IACs) and NIACs, certain violations of which might entail individual criminal responsibility. ${ }^{55}$ This extension of IHL and thereby ICL into NIACs was revolutionary. Traditionally, the focus of IHL had been on inter-State IACs, which were subject to a much more extensive and detailed legal framework than NIACs, which were only governed by Common Article 3 and AP II. This latter fact showed deference to external sovereignty and non-intervention because of reluctance on the part of States to allow international law to interfere in what are essentially domestic affairs. Yet, Tadić showed willingness by an international tribunal to intervene in this municipal reserve. It demonstrates that deference to States is not absolute and that the enforcement of IHL via custom to protect individuals and punish perpetrators, in certain instances, will be of higher importance. Indeed, the Appeals Chamber in Tadić stated that 'a state-sovereignty-oriented approach have [sic] been gradually supplanted by a human-being-oriented approach.' 56

This development has its limits however. Whilst movements in customary ICL have led to a degree of convergence of the two IHL regimes, there has not been a 'full and mechanical transplant' of IHL relating to IACs into that relating to NIACs. Rather, the 'general essence' of those rules is applicable to NIACs. ${ }^{57}$ Therefore, whilst this decision paved the way under ICL for increased individual criminal responsibility during NIACs, the distinction between the two regimes remains. The ICC Statute ${ }^{58}$ follows this trend. It contains two possible prosecution regimes to reflect it, with fewer war crimes in NIACs being subject to the ICC's jurisdiction. 59 There is therefore less ability in NIACs to enforce IHL and ICL norms. Such an approach does not reflect a model that prioritizes human security. Rather, it is indicative of the historical

\footnotetext{
${ }^{51}$ Nuclear Weapons (n 49) para 78.

52 ibid para 79.

${ }^{53}$ Being conflicts not of an international character. See Common Art 3 to the Geneva Conventions and Art 1(1) AP II.

${ }^{54}$ Military and Paramilitary Activities in and against Nicaragua (Nicaragua $v$ US) (Merits) [1986] ICJ Rep 14, para 218; Hamdan v Rumsfeld, Secretary of Defence 126 S. Ct. 2749 (2006) 65-70.

${ }_{55}$ Prosecutorv Tadić (Interlocutory Appeal on Jurisdiction) ICTY-94-1 (2 October 1995) paras 96-136.

56 ibid para 97.

57 ibid para 126.

${ }^{58}$ Rome Statute of the International Criminal Court, 17 July 1998, 2187 UNTS 3 (ICC Statute).

${ }^{59}$ Arts 8(2)(a) and (b) list war crimes applicable in IACs and Arts 8(2)(c) and (e) in NIACs. Notable, is that the first category constitutes a list of 34 potential war crimes whereas only 19 crimes are specified for NIACs.
} 
deference that IHL has paid to States and their external sovereignty. The distinction between IACs and NIACs allows States to retain crucial elements of sovereign protection against interference by IHL and ICL.

The result is that prosecutors and international criminal tribunals face difficult tasks in attempting to classify conflicts with often complex factual backgrounds that may change over time. The consequences of this for ICL are profound, as what particular war crimes may attach to conduct in any given circumstances rests entirely on such classification. The result for victims and the accused may therefore depend on very fine distinctions. This is unsatisfactory for those advocating for the protection of human security. There is a degree of momentum however for eliminating the two-regime system. This is supported by cases such as Tadić, in which the ICTY referred to the compelling humanitarian reasons for reducing, if not eliminating, such distinctions. ${ }^{60}$ The International Committee of the Red Cross (ICRC) study on the customary status of IHL takes a similar view ${ }^{61}$ and Emily Crawford makes a strong case for unification, emphasizing the common denominator of armed conflicts, being human beings. ${ }^{62}$ This is in keeping with the core values of IHL and the basic protections of IHRL that, in principle at least, continue to apply in times of war. ${ }^{63}$ Whilst unification would therefore be welcome, the distinction remains for now.

That humanitarian concerns have influenced the development of IHL may seem supportive of a right of humanitarian intervention. This is because force, even in times of war, is being constrained and what States are allowed to do towards each other and to individuals is increasingly limited. This is the case even if conflict occurs exclusively within the boundaries of a State's own territory. These developments, insomuch as they have been advanced judicially, have occurred absent State consent and it is the individual that is pushed ever more to take the centre stage of international concern. Hamdan is a good example of this and counters the assertion by the second Bush administration that so-called 'unlawful combatants' receive no protections of IHL or IHRL. ${ }^{64}$ As Judge Simma has remarked, there are no legal voids in international law where individuals lack protection. ${ }^{65}$ As such, where IHL safeguards are unclear or absent, it is notable that IHRL and its principles have been drawn on in support, so as to avoid any deficiencies in human security. ${ }^{66}$

Whilst the extent of the ability of IHRL to influence and fill gaps in IHL is controversial, for questions of sovereignty, this is significant as the ability for humanitarian concerns to restrict State power potentially grows. Ultimately however, these IHL developments, even where they draw on IHRL, do not permit States to pierce the veil of external sovereignty of other States or justify force being used to enforce human rights norms in such States. Nor does it allow a third State to intervene to prevent or stop breaches of them. Rather, enforcing IHL and responding to its infringement relies primarily on ascribing individual criminal

\footnotetext{
60 Tadić (n 55) para 126.

${ }^{61}$ International Committee of the Red Cross Study on Customary International Humanitarian Law (2005), available at 〈http://www.icrc.org/customary-ihl/eng/docs/home>.

${ }^{62} \mathrm{E}$ Crawford 'Unequal before the Law: The Case for the Elimination of the Distinction between International and Non-international Armed Conflicts' (2007) 20 Leiden Journal of International Law 441, 465.

${ }^{63}$ Palestinian Wall (n 36) para 106.

${ }^{64}$ See S Borelli, 'Casting light on the legal black hole: International law and detentions abroad in the "war on terror"' (2005) 87 International Review of the Red Cross 39, 47 et seq.

${ }^{65}$ Case Concerning Armed Activities on the Territory of the Congo (Democratic Republic of the Congo v Uganda) (Judgment) [2007] ICJ Rep 168, Separate Opinion of Judge Simma, para 27.

${ }^{66}$ See e.g The Public Committee against Torture in Israel et al v The Government of Israel et al, Judgment, HCJ 769/02, 11 December 2006; Serdar Mohammed v Ministry of Defence [2014] EWHC 1369 (QB). More generally, see K Watkin, 'Controlling the Use of Force: A Role for Human Rights Norms in Contemporary Armed Conflict' (2004) 98 AJIL1.
} 
responsibility. ${ }^{67}$ Whilst belligerent reprisals ${ }^{68}$ have long been used by States as a means to enforce compliance with IHL, since World War II States have increasingly sought to proscribe them by introducing a broad list of specific prohibitions. ${ }^{69}$ Today, their permissibility is extremely limited and their deployment is highly controversial. ${ }^{70}$ Whilst not all States are party to API, the move away from the use of belligerent reprisals is part of a discernable trend to restrain the ability to use force to ensure compliance with international law. Instead, the focus of IHL enforcement is on ex post facto peaceable resolution, via ICL.

\section{International Criminal Law}

The principal concern of ICL is with individuals and their protection from wide-scale atrocities. It thereby shares a common base with IHRL. ${ }^{71}$ Whilst a relatively recent development in international law, springing as it has from the Nuremberg Tribunals following World War II, ICL has gone a long way to place human security at the forefront of international legal development. In respect of an analysis of any right of humanitarian intervention, the precise definition of an international crime may be debated, but it is noteworthy that ICL concerns itself with the most serious crimes that are the concern of the international community as a whole. ${ }^{72}$ For present purposes, these include genocide, crimes against humanity, war crimes and aggression. The first three constitute a way by which ICL responds to violations of certain provisions of IHRL and IHL that concern the protection of individuals. The latter focuses on inter-State conflict and relates to one of the risks to States posed by humanitarian intervention. ${ }^{73}$ Certain other risks will be discussed in Section III.

\section{ICL and the turn to human security}

\footnotetext{
${ }^{67}$ A State may of course invoke the international responsibility of another State for breaches of IHL under the International Law Commission (ILC) Articles on Responsibility of States for Internationally Wrongful Acts, with Commentaries, in Report of the International Law Commission on the work of its fifty-third session, UN Doc A/56/10 (2001) (ARSIWA). Such invocation is subject to peaceable dispute resolution, which will be discussed in Section II(E) below.

${ }^{68}$ A belligerent reprisal 'consists of action which would normally be contrary to [IHL] but which is justified because it is taken by one party to an armed conflict against another party in response to the latter's violation of [IHL] - for example, the use of prohibited weapons in retaliation for their prior use by an adversary.' C Greenwood, Essays on War in International Law (Cameron May 2006) 297. See further F Kalshoven, Belligerent Reprisals (Martinus Nijhoff Publishers 2005).

${ }^{69}$ See Greenwood, ibid 309-315, for discussion of this development and the general trend against the use of belligerent reprisals, most notably pursuant to the express prohibitions stipulated by the four Geneva Conventions of 1949 and API.

${ }^{70}$ For further discussion regarding related controversies and the exceptions to the specific prohibitions, see Greenwood, ibid 315-325; Dinstein (n 45) 253-261. Certain States continue to defend the legality of belligerent reprisals, albeit under strict conditions, see UK Ministry of Defence, The Manual of the Law of Armed Conflict (Oxford University Press 2005) paras 16.16 - 16.19.2.

${ }^{71} \mathrm{R}$ Cryer et al, An Introduction to International Criminal Law and Procedure (2 ${ }^{\text {nd }}$ edn, Cambridge University Press 2010) 3, 13.

${ }^{72}$ See e.g. Arts 1 and 5(1) ICC Statute.

${ }^{73}$ Whilst an agreed definition is lacking under customary international law and the ICC has yet to have its jurisdiction 'activated' for such a crime, humanitarian intervention could potentially lead to individual criminal responsibility for senior military and political leaders for the crime of aggression. See Cryer et al (n 71) 312-333. For analysis that humanitarian intervention might not constitute the crime of aggression, see J Trahan, 'Defining the 'grey area' where humanitarian intervention may not be fully legal, but is not the crime of aggression' (2015) 2 Journal on the Use of Force and International Law 42.
} 
The contribution that ICL has made to human security is significant. As discussed in the previous section, the ICC and customary international law (most notably via the ICTY case law) have increasingly focused on protecting victims of international crimes and bringing the perpetrators to justice. Indeed, the ICTY and the International Criminal Tribunal for Rwanda were specifically set up in response to egregious breaches of human rights. In this respect, ICL serves to enforce IHRL and IHL. Such enforcement is against individuals and, at the international level, is regardless of their official status or seniority, including heads of State. ${ }^{74}$

As part of Teitel's 'humanity law' and Bethlehem's 'tapestry' of justifications for a right of humanitarian intervention, ICL may therefore be viewed as a key component. Whilst its effectiveness may be debated, ICL further entrenches into international law humanitarian values and the protection of individuals. It circumscribes the freedoms of individuals regardless of their position within the State and seeks to hold them to account. ICL thereby limits a State's ability to act within or without its own borders. Importantly, where international law imposes obligations directly on individuals, these transcend the obligations imposed on them by the State. ${ }^{75}$ This superiority of international law means that violations of ICL cannot be justified by reference to national law. ICL thereby contributes to an understanding of sovereignty that recognizes a State's obligation to individuals and also to a higher order of supervision and regulation.

Universal jurisdiction has been an integral part of this normative development. Whilst not without controversy, it is sufficiently well agreed that universal jurisdiction permits the assertion of prescriptive jurisdiction by a State over certain international crimes ${ }^{76}$ in the absence of any other jurisdictional nexus. This includes the lack of any connection based on territory or the nationality of the suspect or victim that links the prosecuting State to the crime in question. ${ }^{77}$ This entitles States to assert jurisdiction over a limited number of offences committed abroad by individuals who are not nationals or residents of that State. This appears supportive of a right of humanitarian intervention, as egregious breaches of human rights are likely to be candidates for these crimes and universal jurisdiction gives any State a potential interest in punishing the perpetrators. It indicates a preference for accountability over deference to sovereignty and points to a focus on human security. In principle at least, States may now concern themselves with actions occurring within other States and to enforce international law where such States are failing to do so.

\section{Impact on external sovereignty}

This right of interference by one State into the domestic sphere of another State based on ICL is limited however. Firstly, as noted above, universal jurisdiction is purely prescriptive and a distinction must therefore be made with the enforcement of ICL. Whilst the ability of a State to prescribe may be extra-territorial, the right to enforce is purely territorial and relies on an alleged perpetrator being within a State's territory. Enforcement jurisdiction cannot be exercised by a State outside its territory, except by virtue of a permissive rule derived from international custom or treaty. ${ }^{78}$ The principles of non-intervention and territorial integrity are therefore preserved by ICL, despite its advancements in protecting individuals and combating impunity. Second, the operation of universal jurisdiction preserves State consent and external

\footnotetext{
${ }^{74}$ See e.g Art 27(1) ICC Statute. Although they may be entitled to immunity from prosecution before domestic courts. See section II(E)(2) below.

${ }^{75}$ Judgment of the Nuremberg International Military Tribunal 1946 (1947) 41 AJIL 172, 221.

${ }^{76}$ These include war crimes, crimes against humanity and genocide, as defined by customary international law, $\mathrm{R}$ O'Keefe, International Criminal Law (Oxford University Press 2015) 22-6.

77 ibid 17-18.

${ }^{78}$ SS "Lotus" (France v Turkey) (1927) PCIJ Ser A, No 10, 18-9.
} 
sovereignty. As with the operation of IHRL, it retains States as 'part of the dialogue', without imposing enforcement of the primary norm upon them. So, whether a State will in fact exercise universal jurisdiction over these core international crimes and prosecute individuals in their territory is a question of right. For customary ICL at least, there does not appear to be any obligation to exercise universal jurisdiction. ${ }^{79}$ This is in contrast to universal jurisdiction grounded in such treaties as the Convention Against Torture (UNCAT) ${ }^{80}$ which imposes an obligation on States to exercise universal criminal jurisdiction, involving a duty to prosecute or extradite an accused present in its territory (an obligation aut dedere aut judicare). ${ }^{81}$ However, such treaty obligation applies only inter partes ${ }^{82}$ and is therefore a consequence of State consent. This has important implications for State immunity, which will be discussed below.

The decisive point for present purposes is that, whilst developments in ICL have increasingly protected individuals, its focus is on ascribing individual criminal responsibility. At the international level, it is a means of enforcing humanitarian protections by holding individuals to account, not States. Crucially, this occurs in a network of courts and tribunals tasked to deal with cases ex post facto. It is also notable that ICL expressly preserves external sovereignty. Domestic courts are seen as an integral part of the ICL framework and the pursuit of impunity. ${ }^{83}$ In fact, the ICC adopts a presumption of State action in respect of enforcement. This is expressed in Article 17 of the ICC Statute, which sets out the principle of complementarity. The focus therefore is on domestic prosecutions, with the ICC only stepping in as a court of last resort where national proceedings fail. This reinforces State power and the principle of non-intervention. It also reminds us that the ICC is a creature of statute and an expression of sovereign will. States may choose (or not) to sign up to the ICC Statute and/or to accept the jurisdiction of the ICC. ${ }^{84}$ These factors together militate against a right of humanitarian intervention.

\section{E. Secondary rules - enforceability and violation}

Humanitarian intervention is preventative in nature: force is deployed to prevent or stop egregious violations of human rights. It is also, per se, a means of enforcing primary human rights norms by the application of military force. The determinative question is whether this approach to violation and enforcement of primary norms fits within the fabric of international law more generally. The foregoing analysis suggests that primary rules of international law are focusing increasingly on human security and that State sovereignty is not inviolable. These positive developments in IHL, IHRL and ICL potentially further the case for a right of humanitarian intervention. This evolution is not unfettered however. As has been demonstrated above, a distinction must be made between, on the one hand, potentially 'humanitarian intervention-friendly' advancements in primary norms of international law and, on the other, the operation of secondary rules that relate to their enforcement and respond to their infringement. These secondary rules are not supportive of Bethlehem's tapestry

\footnotetext{
${ }^{79}$ H Fox and P Webb, The Law of State Immunity (3rd edn, Oxford University Press 2013) 567.

${ }^{80}$ Convention against Torture and Other Cruel, Inhuman or Degrading Treatment or Punishment, 10 December 1984, 1465 UNTS 85.

81 Arts 5-7 UNCAT.

${ }^{82}$ A Cassese, 'Is the Bell Tolling for Universality? A Plea for a Sensible Notion of Universal Jurisdiction' (2003)

1 Journal of International Criminal Justice 589, 594.

${ }^{83}$ Noted in Arrest Warrant of 11 April 2000 (Democratic Republic of the Congo v Belgium) (Judgment) [2002] ICJ Rep 3, Joint Separate Opinion, para 51.

${ }^{84}$ The exception is a UNSC referral to the ICC under Chapter VII UN Charter. An example is the Darfur referral pursuant to UNSC Res 1593 (2005) UN Doc S/RES/1593.
} 
argument for humanitarian intervention. Most significantly, as Crawford notes, inter-State disputes will normally be settled via diplomatic means, with other enforcement processes, including countermeasures and litigation, being very much a last resort. ${ }^{85}$ All such means of dispute resolution however show deference to external sovereignty and the principle of nonintervention. In certain instances, such rules may even specifically prevent enforcement of the primary norms or restrict whether or not redress or remedies are available to victims for their breach. This approach recognizes the fact that international law may necessarily prioritize other concerns over and above the protection of individuals and the enforcement of their rights.

\section{International dispute resolution}

In terms of dispute resolution at the international level, as noted, the jurisdiction of international courts and tribunals operates on the basis of State consent. For any right of humanitarian intervention, this is particularly relevant to the enforcement of IHRL and how international law reacts to infractions. In this regard, at most, States have consented (or not) to monitoring by a treaty body or ex post facto peaceful dispute resolution by a human rights court. This includes the compulsory jurisdiction and binding decisions under the ECHR, which is the strongest example of human rights enforcement at the international level. IHRL does not contemplate a legal option of prevention, enforcement or redress that involves the unilateral use of force. This is the case even if the human rights norm breached has jus cogens status. As $D R C \vee R$ wanda confirms, jurisdiction, and thereby norm enforcement at the international level, is dependent on State consent, even if the breach in question is as serious as genocide. ${ }^{86}$ Also worth noting is the principle of subsidiarity present in both regional and international human rights treaties. This focuses on enforcement at the national level and requires that domestic remedies be exhausted before an individual may seek redress beyond the boundaries of the relevant State. ${ }^{87}$ As with the margin of appreciation given to States to implement the ECHR, deference to sovereignty and State power remains. This shows that, in true R2P-style, the protection of human rights begins with States.

The enforcement of human rights (whether under the UN Charter system, the various UN-backed treaties or the regional regimes) therefore relies on the peaceful settlement of disputes. Redress and any available remedies for victims of violation of human rights norms are provided ex post facto by such dispute resolution. This approach accords with the UN Charter's general emphasis on the peaceful settlement of disputes between nations, ${ }^{88}$ which contributes to the maintenance of international peace and security. It is also in tune with the limitations on how States may protect their own nationals abroad. This is by means of diplomatic protection, which may only be by non-forcible means. ${ }^{89}$ The fact that States do not have a clear right to use force to protect their own nationals abroad does not logically

\footnotetext{
${ }^{85}$ Crawford and Koskenniemi (n 10) 124.

${ }^{86}$ Case Concerning Armed Activities on the Territory of the Congo (Democratic Republic of the Congo $\mathrm{v}$ Rwanda) (Judgment) [2006] ICJ Rep 6, para 64.

${ }^{87}$ E.g. Art 35 ECHR.

${ }^{88}$ Arts 1(1), 2(3), 33 UN Charter. This is echoed by the Friendly Relations Declaration affirmation of the 'principle that States shall settle their international disputes by peaceful means in such a manner that international peace and security and justice are not endangered.'

${ }^{89}$ Art 1 of The ILC Draft Articles on Diplomatic Protection (2006), UN Doc A/CN.4/SER.A/2006/Add.1 (Part 2) confines the definition of diplomatic protection to 'diplomatic action or other means of peaceful settlement'. The right to use force more generally to protect nationals is controversial and academic opinion and State practice is divided. See e.g C Gray, International Law and the Use of Force (3rd edn, Oxford University Press 2008) 156160 .
} 
support a right of intervention to protect the nationals of another State where their rights are being abused. The result is that this most classic expression of State sovereignty (i.e a State protecting its own rights ${ }^{90}$ ) is subject to the weightier considerations of the non-use of force and the territorial integrity of the State in which the national is located.

Ultimately, consent to jurisdiction and to peaceful dispute resolution preserves external sovereignty and the principle of non-intervention. It demonstrates that enforcement of primary rules of international law and responses to their violation are contingent on State consent. This is regardless of the status of the norm or the gravity of the breach. Sovereignty may thereby act as a shield to prevention or enforcement at the international level. That international law so strongly prioritizes consent for the enforcement of public order norms is not supportive of any putative right of humanitarian intervention. Both consent and territorial integrity are key elements of sovereignty. However, a violation of the latter by an exercise of humanitarian intervention is more serious than dispensing with the former, due to the potential ensuing risks for international peace and security in the event of escalation. Therefore, as State consent is preserved and protected as a foundational principle of the international legal system, a logical corollary to this fact is that territorial integrity should likewise be preserved by its attendant guardian principle of non-intervention. These principles feed into maintaining peace and stability. Whenever there is any tension or conflict between human rights and peace therefore, peace must always prevail. ${ }^{91}$

\section{2. $\quad$ Domestic dispute resolution}

This trend continues in the national forum. In terms of enforcement options in domestic courts and how victims may seek redress there, the default premise is that States may not exercise the jurisdiction of their courts over other States. The proper forum for redress in such circumstances is the invocation of an internationally wrongful act against such State. ${ }^{92}$ That said, an inroad has been made in respect of functional immunity ${ }^{93}$ in criminal cases. This is in keeping with the growing importance of ICL and IHRL and exemplifies that the shield of sovereignty is increasingly permeable and cannot be used to flout individual rights. In Pinochet, ${ }^{94}$ which is the leading authority on this development, the House of Lords handed down a ground-breaking judgment that Senator Pinochet was not entitled to immunity ratione materiae in respect of the international crime of torture. The Pinochet rationale shows that those who breach human rights and commit crimes of international concern may face justice by being held criminally responsible before municipal courts. This approach prioritizes to some degree individual rights over respect for State sovereignty and immunity. It shows that the latter is a relative concept and that international law is willing to introduce accountability into the equation. However, the rationale and proper extent of this exception to functional immunity is controversial. It is a nascent development and it is notable that immunity ratione personae remains an absolute bar to both criminal and civil domestic proceedings (although debate remains over which senior officials benefit). ${ }^{95}$ Immunity as a function of external sovereignty thereby remains central to international law.

\footnotetext{
${ }^{90}$ By diplomatically protecting their citizens, States protect their own sovereign rights, not those of the individual. Mavrommatis Palestine Concessions (Greece v U.K.) (1924) PCIJ Ser A, No 2, 12.

${ }^{91}$ A Cassese, 'Ex iniuria ius oritur: Are We Moving towards International Legitimation of Forcible Humanitarian Countermeasures in the World Community?' (1999) 10 EJIL 23, 24.

${ }^{92}$ Fox and Webb (n 79) 537.

${ }^{93}$ Or immunity ratione materiae, that attaches to the acts of State officials.

${ }^{94} R$ v Bow Street Metropolitan Stipendiary Magistrate and Others, Ex parte Pinochet Ugarte (No. 3) [2000] 1 AC 147.

${ }^{95}$ Arrest Warrant (n 83) para 51.
} 
In addition, the exception to immunity does not apply to civil proceedings. ${ }^{96}$ This distinction is important for the review of external sovereignty. In Germany v Italy, following its approach in DRC $v$ Rwanda, the ICJ confirmed that rules on immunity are procedural and cannot conflict with substantive jus cogens norms. ${ }^{97}$ This strict procedure/substance distinction is open to criticism, especially given the gravity of the alleged breaches in question and the fact that no alternative remedy was available to the claimant. Furthermore, in respect of universal jurisdiction, the distinction is less clear as the substance of the norm has important procedural consequences. ${ }^{98}$ Ultimately, where enforcement of the norm and an effective remedy for its breach are blocked by immunity, this is not simply a question of procedure.

Yet, given this approach by the various domestic and international courts, the distinction is likely to be followed going forward. It shows that, regardless of the consequential restriction on access to justice, the gravity of the breach in question or the status of the norm breached, international law may prioritize States and their external sovereignty over individual redress and remedies and even life itself. Crucially, it may be right to do so. The Pinochet exception services the premise that ICL, in attributing criminal responsibility to individuals (and fighting impunity), has less need to shield officials from responsibility that would normally attach to their State. In the civil context however, the adherence to State immunity is both proportionate and necessary 'to promote comity and good relations between States through the respect of another State's sovereignty'. ${ }^{99}$ It recognizes that immunity is required for the proper functioning of international relations and the freedom of movement and action of diplomats and officials, all of which contribute to international peace and security. As noted in the previous section, international law may therefore have priorities over and above individual rights. Respect for external sovereignty, by granting immunity, is an essential element of this fact.

\section{Wrongfulness preclusion - countermeasures and necessity}

In terms of other secondary rules of international law, if humanitarian intervention could constitute a countermeasure, then this would preclude any wrongfulness that would otherwise be incurred by an internationally wrongful act (being a breach of Article 2(4) UN Charter). ${ }^{100}$ Article 48(1)(b) ARSIWA envisages that States other than an 'injured State' may invoke responsibility in the collective interest for breaches of obligations 'owed to the international community as a whole'. This codification of the Barcelona Traction dictum recognizes that certain obligations (including genocide and basic human rights) are erga omnes and are therefore the concern of all States. ${ }^{101}$ This right of standing for third States to invoke an internationally wrongful act on an actio popularis basis might seem supportive of a right of humanitarian intervention. However, the right has limits. Whilst so called 'non-injured States' may have an interest in the breach of an obligation erga omnes and may call for its cessation and for reparations under Article 48(2) ARSIWA, Article 54 only contemplates such States taking lawful measures against the wrongdoing State. The ILC commentary on Article 54 concludes however, that there is no clearly recognized right to take collective

\footnotetext{
${ }^{96}$ Al-Adsani v United Kingdom (2001) 34 EHRR 273; Jones v Saudi Arabia [2006] UKHL 26; Jurisdictional Immunities of the State (Germany v Italy: Greece intervening) (Judgment) [2012] ICJ Rep 99.

97 ibid paras 58, 93, 100.

${ }^{98}$ See K N Trapp and A Mills, 'Smooth Runs the Water Where the Brook is Deep: The Obscured Complexities of Germany v Italy' (2012) 1(1) Cambridge Journal of International and Comparative Law 153, 159-163.

${ }^{99}$ Al-Adsani (n 96) para 54.

100 Art 22 ARSIWA.

${ }^{101}$ Barcelona Traction (n 29) paras 33-34.
} 
countermeasures ${ }^{102}$ and, in any event, it is clear that countermeasures may not involve the threat or use of force. ${ }^{103}$ Therefore, whilst an egregious breach of human rights triggers the right of the wider international community to invoke State responsibility, the abilities of such third States to respond to a breach are expressly limited to peaceful means. There is no right under the laws of State responsibility to use force to suppress or prevent it.

As an alternative to countermeasures, States may invoke necessity to preclude the wrongfulness of an act if it 'is the only way for the State to safeguard an essential interest against a grave and imminent peril'. ${ }^{104}$ The ILC commentary to Article 25 refers to essential interests of the State or of the international community as a whole. ${ }^{105}$ Relying on necessity to excuse an otherwise illegal use of force on the basis that it is used to suppress or prevent violations of obligations erga omnes faces significant problems however. Firstly, Article 25 is drafted in the negative, with the ICJ's conclusion being that States may only invoke it in exceptional circumstances. ${ }^{106}$ Second, invocation is disbarred if the international obligation in question (being Article 2(4) UN Charter) excludes the possibility of invoking necessity. ${ }^{107}$ If we accept that Article 2(4) constitutes an absolute prohibition on the use of force, subject only to the explicit exceptions set out in the UN Charter, then on its own terms Article 2(4) likely prevents wrongfulness preclusion on the basis of humanitarian intervention. A fortiori if Article 2(4) is characterised as jus cogens. ${ }^{108}$ Lastly, and perhaps most importantly, necessity may not be invoked where the actions taken 'seriously impair an essential interest of the State or States towards which the obligation exists, or of the international community as a whole.' ${ }^{109}$ The interest relied on (being the protection of human security) must therefore outweigh all other considerations. ${ }^{110}$ For a right of humanitarian intervention, this seems an impossible conclusion to draw given the foundational and essential interests of external sovereignty and territorial integrity that are violated by intervention and its wider implications for international peace and security. As such, a plea of necessity is not supportive of a right of humanitarian intervention.

\section{THE DANGERS OF HUMANITARIAN INTERVENTION}

The focus of international law therefore in enforcing human rights norms and responding to their breaches is on ex post facto peaceful dispute resolution and holding individual perpetrators to account under ICL. Preventative action using force is not an option. The operation of secondary rules emphasize that fact and, in so doing, prioritize international peace

\footnotetext{
102 Commentary to Art 54 ARSIWA, paras 2-6.

${ }^{103}$ Art 50(1)(a) ARSIWA.

${ }^{104}$ Art 25(1) ARSIWA.

105 Commentary to Art 25 ARSIWA, para 2.

106 Gabčikovo-Nagymaros Project (Hungary/Slovakia) (Judgment) [1997] ICJ Rep 7, para 51.

${ }^{107}$ Art 25(2)(a) ARSIWA.

${ }^{108}$ Art 26 ARSIWA denies a preclusion of wrongfulness where a jus cogens norm is violated. The Art 2(4) prohibition is sometimes described as having this peremptory status (see e.g. B Simma, 'NATO, the UN and the use of force: Legal Aspects' (1999) 10 EJIL 1, 3). Such characterisation is highly controversial however. In Nicaragua (n 54), para 190, the ICJ noted that the ILC and the United States (in its Memorial on the Merits in the case) characterised the prohibition on the use of force as jus cogens, but it has never ruled on this point.

${ }^{109}$ Art 25(1)(b) ARSIWA.

${ }^{110}$ Commentary to Art 25 ARSIWA, para 17.
} 
and security. Yet, these peaceable routes to implementation, accountability and justice are not always available. In respect of Syria for example, one concern has been the lack of means by which to achieve justice and accountability for victims. ${ }^{111}$ However, even where human rights protection is absent or where justice may go unanswered for their breach, this does not mean that humanitarian intervention should be used to prevent or stop human rights abuses. Nor should it be applied to fill any gaps in either the enforcement or the accountability framework. The dangers of humanitarian intervention (not addressed by Bethlehem when knitting together his tapestry argument) are too great.

These dangers, for the State intervening, the State in whose territory the intervention is occurring and for the people who reside there, are many. A full discussion of them is beyond the confines of this article. For present purposes and the consideration of the effect on the wider fabric of international law however, it is worth highlighting two key dangers. The first is the essential, and essentially non-legal, question of whether military interference might improve the situation or make it worse. Libya is not an example of humanitarian intervention, as it took place under the auspices of a UNSC authorisation to use all necessary measures to protect the civilians of Libya. ${ }^{112}$ However, it exemplifies the difficulties involved in this analysis. Whilst humanitarian aims were expressed at the time of the intervention, Germany and Brazil for example raised concerns in the UNSC that intervention might make matters worse. ${ }^{113}$ Such concerns were prescient. Today, the human rights situation in Libya remains appalling, with purported violations of IHRL, IHL and ICL and the breakdown of security and the rule of law. ${ }^{114}$ Libya is now viewed as a failed State. ${ }^{115}$ This begs the question whether the humanitarian goals were ultimately achieved and whether it is ever possible to say for definite that intervention will or can lead to the improvement of usually very complicated situations on the ground. In short, can humanitarian intervention really be said to be capable of advancing humanitarianism and human security in the way that might be envisaged?

The second and, perhaps main, practical argument against a right of humanitarian intervention is its auto-determinative nature. Such a right would give competence to a State (or group of States), acting outside UNSC authorization and the collective security framework of the UN Charter, to breach the territorial integrity of another State. States would therefore be granted the capacity to assess the effectiveness of the UNSC and, if judged to be failing, to act in its stead. This is contrary to the content and spirit of the UN Charter and is dangerous for international peace and security and the primacy of the UNSC in protecting it. Unilateral intervention to protect human security should not become an independent exception or substitute for collective action. This is particularly so when one considers the potential motives for humanitarian intervention, which may be political or geared towards certain foreign policy objectives. The fear is therefore of abuse of the right, whereby stronger States use humanitarian intervention as a pretext for interfering in their less powerful neighbours. Russia's recent statements and actions regarding Ukraine are a case in point and show how humanitarian intervention can fit neatly into a powerful neighbour's alternative foreign policy agenda. In this

\footnotetext{
${ }^{111}$ Statement by Mr. Paulo Sérgio Pinheiro Chair of the Independent International Commission of Inquiry on the Syrian Arab Republic United Nations Human Rights Council (March 2015), available at <http://www.ohchr.org/EN/NewsEvents/Pages/DisplayNews.aspx?NewsID=15843\&LangID=E >

112 UNSC Res 1973 (2011) UN Doc S/RES/1973.

${ }^{113}$ UNSC Verbatim Record (17 March 2011) UN Doc S/PV.6498.

${ }^{114}$ For details, see the United Nations Support Mission in Libya and Office of the United Nations High Commissioner for Human Rights, 'Report on the Human Rights Situation in Libya' (16 November 2015), available at

<http://unsmil.unmissions.org/Portals/unsmil/Documents/Joint\%20OHCHR\%20UNSMIL\%20report\%2016\%20 $11 \% 2015 \% 20 \mathrm{EN} . \mathrm{pdf}>$.

115 The Washington Institute, 'Libya as a Failed State: Causes, Consequences, Options' (November 2014), available at <http://www.washingtoninstitute.org/uploads/Documents/pubs/ResearchNote24_Engel-3.pdf $>$.
} 
case, President Putin drew on Kosovo as a precedent for intervention in Ukraine, stating that it was 'a humanitarian mission'. ${ }^{116}$ This shows the dangers of setting precedents of humanitarian intervention and adopting wide R2P style terminology as a pretext for aggressive and unlawful behaviour. This raises a further difficulty of how such actions are to be reviewed and how they may be held accountable. ${ }^{117}$ Regime change ${ }^{118}$ and other more dubious grounds for intervention that suit a State's own national foreign policy or security interests might also be mixed up with alleged humanitarian concerns. The proper purpose of the use of force for any right of humanitarian intervention is essential therefore and where other motivations for intervention are also present, they cast doubt on the morality and legitimacy of any humanitarian objectives. Uses of force cannot and should not serve as a short cut to international justice or as a means of punishment. ${ }^{119}$

\section{CONCLUSION}

Bethlehem's tapestry argument provides a degree of superficial support for a right of humanitarian intervention. As does the paradigm shift towards Teitel's humanity law, where normative foundations are emphasizing human rather than State security. This pluralistic understanding of sovereignty demonstrates that international law is less State centric and that sovereignty is conditional and a responsibility. However, these developments only take the argument for humanitarian intervention so far. The evolution of IHRL, IHL and ICL is progressive and on-going and, whilst the focus on individuals and their security is increasing, its ability to account for humanitarian concerns is circumscribed. Vitally, secondary rules that might enforce or reflect these developments are weak. There is therefore a lack of support in the turn to 'humanity law' or any right of humanitarian intervention. Instead, these rules underscore State consent, peaceful dispute resolution and ex post facto accountability. The latter is notably via ICL, where enforcement and accountability take place in a courtroom rather than through military means. Therefore, whilst individuals are seen increasingly as bearers of rights and active subjects or participants in international law, there are limitations on their protection and the potential for international law to monitor and curb State power.

The reports of the death of sovereignty are thereby much exaggerated, ${ }^{120}$ but the nature of both internal and external sovereignty has certainly changed in the post war years. States do not have absolute discretion to act within or without their own borders. However, the restrictions on either type of sovereignty must not be overstated. In particular, even if we understand it to be less State-centric, external sovereignty in the Westphalian sense remains at the core of international law. Whilst it no longer provides a licence to abuse human rights underneath an impermeable shell of protection, it may still act as a shield to the enforcement of primary norms. States are not the sole centres of legal power, but they remain the only 'full legal person' on the international stage and sovereignty remains a strong bulwark against

\footnotetext{
116 Transcript of President Putin's interview, Washington Post (4 March 2014) $<$ http://www.washingtonpost.com/world/transcript-putin-defends-russian-intervention-inukraine/2014/03/04/9cadcd1a-a3a9-11e3-a5fa-55f0c77bf39c_story.html>.

${ }^{117}$ See e.g. N Rodley and B Cali, 'Kosovo Revisited: Humanitarian Intervention on the Fault Lines of International Law' (2007) 7 Human Rights Law Review 275, 295-297 for a discussion of this problematic issue.

118 Which became a goal of the Libya intervention. See B Pommier, 'The use of force to protect civilians and humanitarian action: the case of Libya and beyond' (2011) 884 International Review of the Red Cross 1063, 10671069.

${ }^{119}$ C Stahn, 'Syria and the Semantics of Intervention, Aggression and Punishment: On 'Red Lines' and 'Blurred Lines" (2013) 11 (5) Journal of International Criminal Justice 955.

${ }^{120}$ Crawford in Crawford and Koskenniemi (n 10) 132.
} 
external interference and intervention. This may even extend, as seen in the case of immunity, to trumping breaches of human rights.

These secondary rules create their own tapestry of international law, one that recognizes higher priorities such as the prohibition on the use of force, ${ }^{121}$ the comity of nations and the proper functioning of the international order. A right of humanitarian intervention would endanger this. The very concept risks tearing a hole in that tapestry. Therefore, when the enforcement and protection of human rights is pitted against preserving external sovereignty and international peace and security, human rights must lose. In addition, as part of assessing the role of humanitarian intervention in the international legal order, the risks and dangers of its abuse, doubts as to its efficacy and its position in the wider context of collective security raise substantial concerns. Article 2(4) is under great strain in the post 9/11 world and further exceptions would only further endanger international peace and stability. That said, placing the exclusive right to use force to protect human rights in the hands of the UNSC raises its own issues. As the case of Syria shows, the power of the veto may prove fatal to preventing humanitarian disasters. Yet, rather than pointing to a need for humanitarian intervention, this arguably speaks more strongly in favour of institutional and procedural reform of the UN. Ultimately, none of Bethlehem's 'threads' on their own support a right of humanitarian intervention and weaving them together does not make the fabric any stronger. A close analysis shows that the tapestry all too easily unravels. The result is that, even if the wider fabric of international law points to a pluralistic understanding of sovereignty, a right of humanitarian intervention does not and should not fit within it.

${ }^{121}$ Whilst not establishing an independent right to use force, considerations of pluralistic sovereignty are relevant to the scope of the right of self-defence against NSAs, based on the 'unwilling or unable' doctrine. See Trapp (n $14)$. 